\title{
HUBUNGAN OBESITAS DAN AKTIVITAS FISIK DENGAN KEJADIAN DIABETES MELITUS TIPE II DI WILAYAH KERJA PUSKESMAS OLAK KEMANG TAHUN 2018
}

\section{Obesity Relationship and Physical Activity With Diabetes Type 2 in Olak Kemang Community Health Center}

\author{
Sintia Tri Handayani ${ }^{1}$ Hubaybah $^{2}$ Dwi Noerjoedianto ${ }^{2}$ \\ ${ }^{1}$ Program Studi Ilmu Kesehatan Masyarakat Universitas Jambi \\ ${ }^{2}$ Dosen Ilmu Kesehatan Masyarakat, Fakultas Kesehatan Masyarakat, Universitas Jambi
}

\begin{abstract}
Abstrak
Prevalensi di Puskemas Olak Kemang Kota Jambi memiliki peringkat pertama dari 20 Puskesmas yang ada di Kota Jambi. Penelitian ini bertujuan untuk mengetahui faktor risiko obesitas dan aktivitas fisik yang berhubungan dengan kejadian DM tipe II di Wilayah Kerja Puskesmas Olak Kemang Kota Jambi 2018. Penelitian menggunakan rancangan case control dengan teknik probability sampling dengan jumlah sampel 100 responden. Data dianalisis dengan uji Chi Square dengan CI: 95\% dan $\alpha=0,05$. Hasil penelitian menunjukan bahwa gambaran obesitas dan aktivitas fisik di wilayah kerja Puskesmas Olak Kemang yaitu responden yang obesitas $(52,0 \%)$, responden yang tidak obesitas $(48,0 \%)$ dan responden yang memiliki aktivitas fisik cukup (97,0\%), responden yang memiliki aktivitas fisik rendah $(3,0 \%)$. Faktor yang berhubungan dengan kejadian DM tipe II adalah obesitas nilai $\mathrm{p}$ value $=0,001$; OR $=4,529$ yaitu seseorang yang memiliki obesitas beresiko 4 kali lipat mengalami DM tipe II dari yang tidak memiliki obesitas. Sedangkan faktor yang tidak berhubungan dengan kejadian DM tipe II adalah aktivitas fisik p value $=1,000 ; \mathrm{OR}=0,490$ yaitu aktivitas fisik merupakan faktor protektif terhadap kejadian DM tipe II. Kesimpulan dari penelitian ini yaitu terdapat hubungan yang signifikan antara obesitas dengan kejadian DM tipe II di Puskesmas Olak Kemang Kota Jambi 2018
\end{abstract}

Kata Kunci : Diabetes Melitus Tipe II, Obesitas, Aktivitas Fisik

\begin{abstract}
Diabetes type II most commonly found in public health center Olak Kemang among 20 Puskesmas in Jambi City. Theoretically, the increase of DM prevalence is influenced by some risk factors. Risk factors of diabetes type II include obesity and physical activity. This study aims to determine the association of obesity and physical activity as risk factors with the incidence of type II DM in the public health center Olak Kemang municipality of Jambi 2018. This was an observational analytic study using case control design. Samples obtained by using probability sampling technique with the numbers of samples 100 respondents. Data were analyzed by Chi Square test with CI: $95 \%$ and $\alpha=0,05$. Result indicated respondents with obesity $(52,0 \%)$, and respondents without obesity $(48,0 \%)$, meanwhile respondents who do enough physical activity $(97,0 \%)$, and respondents who do less physical activity $(3,0 \%)$. The associated factors of DM type II incidence is obesity with pvalue $=0,001 ; \mathrm{OR}=4,529$, means somebody with obesity risks to have type II DM 4 times more than those who doesnt. Also, physical activity with pvalue $=1,000 ; \mathrm{OR}=0,490$ only plays role as the protective factor of type II of DM incidence. In conclusion of this study is that there is a significant association between obesity and the incidence of DM type II in Public health center Olak Kemang municipality of Jambi 2018
\end{abstract}

Keywords: Diabetes Mellitus type II, Obesity, Physical Activity

Korespondensi : Sintia Tri Handayani

Email:Sintiatri_handayani@yahoo.co.id 


\section{PENDAHULUAN}

Diabetes melitus (DM) atau disingkat diabetes adalah gangguan kesehatan yang berupa kumpulan gejala yang disebabkan oleh peningkatan kadar gula (glukosa) darah akibat kekurangan ataupun resistensi insulin. Penyakit ini sudah lama dikenal, terutama dikalagan keluarga, khususnya keluarga berbeda besar (kegemukan) bersama dengan gaya hidup yang tinggi (Hermanu Kurniadi \& Ulfa Nurrahmani, 2015).

Hal ini dapat dilihat dari jumlah penderita dan prevalensi diabetes melitus (DM) yang meningkat dimasa yang akan datang, dimana menurut WHO jumlah penderita DM meningkat dari 171 juta di tahun 2000 menjadi 366 juta pada tahun 2030. Pada tahun 2015, diperkirakan 1,6 juta kematian secara langsung disebabkan oleh diabetes melitus. WHO juga memproyeksikan bahwa diabetes melitus akan menjadi penyebab kematian ketujuh di tahun 2030 (WHO, 2017).

Peningkatan prevalensi akan lebih menonjol perkembangannya di negara berkemabang dibandingkan dengan negara maju, dimana Indonesia termasuk salah satu negara berkembang dengan prevalensi DM di Indonesia besarnya $1,2 \%-2,3 \%$ dari penduduk usia lebih dari 15 tahun. Pada prevalensi DM di Indonesia mencapai jumlah 8.426 .000 (tahun 2000) yang diproyeksikan mencapai 21.257.000 pada tahun 2030. Artinya, terjadi kenaikan tiga kali lipat dalam waktu 30 tahun (Bustan, 2015)

Data Riskesdas tahun 2013 angka prevalensi penyakit DM 2,1\% di Provinsi Jambi. Berdasarkan hasil laporan PTM Provinsi Jambi tahun 2014 menunjukan bahwa penyakit DM merupakan kasus penyakit tertinggi. DM merupakan urutan ke 2 dari 17 PTM lainnya, dengan jumlah kasus sebesar 12.461 orang
Dinkes Provinsi Jambi 2014 (Kementerian Kesehatan Republik Indonesia, 2014). Diabetes Melitus memiliki 3 tipe yaitu DM tipe I, DM tipe II dan DM gestational (WHO,2017). Pada DM tipe II jumlah penderita lebih banyak sekitar 90-99\% (Helmanu \& Ulfa, 2015). Berdasarkan beberapa faktor risiko DM tipe II faktor yang memiliki peran adalah obesitas dan kurangnya aktivitas fisik (Padmiarso.M.Wijoyo,2011). Berdasarkan Riseksdas 2013 prevalensi obesitas $(15,4 \%)$ merupakan salah satu faktor risiko terbesar DM. (Helmanu Kurniadi \& Ulfa Nurrahmani. 2015).

DM tipe II mempunyai berbagai faktor risiko baik genetik maupun lingkungan. Pada umumnya DM tipe II biasanya terjadi pada orang dewasa, akan tetapi biasa terjadinya setelah usia 30 tahun (Mirza Maulana, 2008). Dalam masyarakat, mereka yang kelompok risiko tinggi (high risk group) DM yaitu usia lebih dari 45 tahun, berat badan lebih (BBR $>110 \%$ atau IMT $>25 \mathrm{~kg} / \mathrm{m}$ ), hipertensi (>140/90 mmHg ), riwayat keturunan DM, dan kurang aktivitas fisik (Bustan, 2015).

Berdasarkan data dari Dinas Kesehatan Kota Jambi tahun 2016 penyakit dengan kasus baru terbanyak pada PTM yaitu diabetes melitus merupakan urutan ke-2 dari penyakit hipertensi , asma, cedera akibat lain, dan obesitas. Alas an mengapa mengambil kota Jambi dan DM tipe II dikarenakan penduduk yang tinggal di kota lebih tinggi angka kesakitannya di bandingkan di perdesa. Dari data prevalensi nasional penyakit diabetes di Indonesia adalah $2,1 \%$. Tetapi pada faktanya prevalensi diabetes melitus daerah perkotaan melebihi prevalensi nasional yaitu sebesar 5,7 $\%$. Dari 20 Puskesmas yang terdapat dikota Jambi, Olak Kemang merupakan Puskesmas yang memiliki prevalensi tertinggi yang masyarakatnya banyak menderita DM tipe II. 
Prevalensi tersebut yaitu sebesar 4,7\% (Dinas Kesehatan Kota Jambi, 2016).

\section{METODE}

Penelitian ini menggunakan metode analitik observasional dengan pendekatan case control. Kasus dan kontrol bisanya dipilih dari populasi sumber yang sama. Sehingga kedua kelompok memiliki karakteristik yang sebanding kecuali status penyakit. Peneliti mengukur paparan pada waktu yang lalu (retrospektif) dengan cara wawancara, mengkaji catatan medik (Murti, 2016). Berdasarkan rancangan tersebut penelitian secara skema case control (restrofektif) dari adanya paparan penyakit ditelusuri kebelakang faktor risiko yang mempengaruhi dari paparan penyakit.

Lokasi penelitian yang akan dilakukan adalah di Wilayah Kerja Puskesmas Olak Kemang Kecamatan Danau Teluk Kota Jambi. Wilayah kerja Puskesmas Olak Kemang meliputi 5 kelurahan yaitu kelurahan Pasir Panjang, Tanjung Raden, Tanjung Pasir, Olak Kemang, dan Ulu Gedong. Adapun waktu penelitian yang direncanakan peneliti dilakukan pada bulan April-Mei 2018. Sampel pada penelitian ini adalah 50 orang, dengan perbandingan 1:1 antara kasus 50 dan kontrol 50 sehingga total sample adalah 98 orang yang berada di wilayah kerja Puskesmas Olak Kemang. Teknik pengambilan sample dilakukan dengan non probabilitas (probability sampling) dengan simple random sampling.

Instrumen yang digunakan dalam penelitian ini adalah kuesioner. Kuesioner yang digunakan dalam penelitian ini dibagi dalam 4 bagian yaitu bagian pertama berisikan tentang identitas responden berupa nama lengkap, alamat, dan no HP. Bagian kedua berisikan karakteristik responden yang terdiri dari jenis kelamin, pendidikan, pekerjaa, riwayat diabetes melitus tipe II. Bagian ketiga merupakan kuesioner yang digunakan untuk mengetahui obesitas di ukur dengan menggunakan kuesioner Riskesdas 2013 dengan melihat berat badan dan tinggi badan, sedangkan dibagian keempat merupakan kuesioner aktivitas fisik dengan mengunakan kuesioner GPAQ ( Global Physicaal Activity Questionnaire) v2 yang memilki beberapa pertanyaan yang dilihat dari rendah dan cukup aktivitas fisik yang dilakukan dengan klasifikasi sesuai kriteria yang ada pada masing-masing bagian.

Pengambilan data penelitian ini dilakukan setelah mendapatkan izin dari puskesmas, lalu memberikan penjelasan tentang penelitian yang dilakukan kepada calon responden, meminta kesediaan untuk menjadi responden dan mengisi informed consent, memberikan wawancara terhadap kuesioner yang ada, serta memeriksa kembali kelengkapan jawaban kuesioner yang dijawab oleh responden. Data yang diperoleh selanjutnya diolah menggunakan analisis data software SPSS (Statistical Program for School Sciences), analisis univariat dan uji chi square. 


\section{HASIL}

Karakteristik sosiodemografi responden di wilayah kerja Puskesmas Olak Kemang Kota Jambi berupa jenis kelamin, usia, pekerjaan dan pendidikan yang dapat dilihat pada tabel dibawah ini:

Tabel 1.

Distribusi Responden Berdasrkan Karakteristik Sosiodemografi dengan DM Tipe II diwilayah Kerja Puskesmas Olak Kemang Kota Jambi 2018

\begin{tabular}{|c|c|c|c|c|c|c|}
\hline \multirow[t]{2}{*}{ Karakteristik } & \multicolumn{2}{|c|}{ Kasus } & \multicolumn{2}{|c|}{ Kontrol } & \multirow[b]{2}{*}{$\mathrm{n}$} & \multirow[b]{2}{*}{$\%$} \\
\hline & $\mathrm{n}$ & $\%$ & $\mathrm{n}$ & $\%$ & & \\
\hline \multicolumn{7}{|l|}{ Jenis Kelamin } \\
\hline Laki-laki & 15 & 30,0 & 16 & 32,0 & 31 & 31,0 \\
\hline Perempuan & 35 & 70,0 & 34 & 68,0 & 69 & 69,0 \\
\hline \multicolumn{7}{|l|}{ Usia } \\
\hline$\geq 45$ tahun & 46 & 92,0 & 26 & 52,0 & 72 & 72.0 \\
\hline$<45$ tahun & 4 & 8,0 & 24 & 48,0 & 28 & 28,0 \\
\hline \multicolumn{7}{|l|}{ Pendidikan } \\
\hline Tinggi & 3 & 6.0 & 4 & 8,0 & 7 & 7,0 \\
\hline Rendah & 47 & 94.0 & 46 & 92,0 & 93 & 93,0 \\
\hline \multicolumn{7}{|l|}{ Pekerjaan } \\
\hline PNS & 4 & 8,0 & 3 & 6,0 & 7 & \\
\hline Pegawai swasta & 3 & 6,0 & 1 & 2,0 & 4 & \\
\hline Wiraswasta & 5 & 10,0 & 8 & 16,0 & 13 & \\
\hline Petani & 3 & 6,0 & 1 & 2,0 & 4 & \\
\hline Buruh & 3 & 6.0 & 4 & 8,0 & 7 & \\
\hline Lainnya & 2 & 4,0 & 2 & 4,0 & 4 & \\
\hline IRT & 29 & 58,0 & 30 & 60,0 & 59 & \\
\hline Pensiunan & 1 & 2,0 & 1 & 2,0 & 2 & \\
\hline
\end{tabular}

Karakteristik

Pensiunan

2,0

$(94,0 \%)$ dan

responden menurut jenis kelamin responden pada kelompok kasus dan kontrol paling banyak berjenis kelamin perempuan. Pada kelompok kasus sebanyak $35(70,0 \%)$ dan kontrol 34 $(68,0 \%)$. Berdasarkan umur, sebagian besar responden baik pada kelompok kasus maupun kontrol paling banyak berusia diatas 45 tahun. Pada kelompok kasus sebanyak $46(92,0 \%)$ dan kontrol 26 ( 52,0\%).

Berdasarkan pendidikan responden, baik pada kelompok kasus maupun kontrol sebagian besar responden memiliki pendidikan yang rendah. Pada kelompok kasus sebanyak 47 kontrol 46 (92,0\%). Pada kelompok yang menderita diabetes mellitus tipe 2. Karakteristik responden menurut jenis pekerjaan, sebagian besar responden baik pada kelompok kasus maupun kontrol adalah ibu rumah tangga (IRT). Pada kelompok kasus IRT sebanyak 29 (58,0\%) dan kontrol $30(60,0) \%$, sedangkan pekerjaan yang terendah pada kelompok kasus dan kontrol adalah pesiunan, untuk kelompok kasus sebanyak 1 (2,0\%) dan kontrol 1 (2,0\%).

Berikut adalah hasil analisis hubungan antara variabel obesitas dengan diabetes melitus 
tipe II di Puskesmas Olak Kemang Kota Jambi

Tahun 2018:

Tabel 2.

Hubungan Obesitas dan Aktivitas Fisik dengan DM Tipe II di Puskesmas Olak Kemang Kota Jambi Tahun 2018

\begin{tabular}{|c|c|c|c|c|c|c|c|c|c|}
\hline \multirow{2}{*}{ Variabel } & & \multicolumn{2}{|c|}{ Kasus } & \multicolumn{2}{|c|}{ Kontrol } & \multicolumn{2}{|c|}{ Total } & \multirow{2}{*}{$\begin{array}{l}P \\
\text { Value }\end{array}$} & \multirow{2}{*}{$\begin{array}{l}\text { OR } \\
(95 \% \text { CI })\end{array}$} \\
\hline & & $\mathrm{n}$ & $\%$ & $\mathrm{n}$ & $\%$ & $\mathrm{n}$ & $\%$ & & \\
\hline \multicolumn{10}{|l|}{ Obesitas } \\
\hline $\begin{array}{l}\text { Obesitas } \\
25 \mathrm{~kg} / \mathrm{m}^{2} \text { ) }\end{array} \quad$ (IMT & $\geq$ & 35 & 70,0 & 17 & 34,0 & 52 & 52,0 & \multirow[b]{2}{*}{0,001} & \multirow{2}{*}{$\begin{array}{c}4,529 \\
(1,952-10,508)\end{array}$} \\
\hline $\begin{array}{l}\text { Tidak Obesitas } \\
\left(\text { IMT }<25 \mathrm{~kg} / \mathrm{m}^{2}\right)\end{array}$ & & 15 & 30,0 & 33 & 66,0 & 48 & 48,0 & & \\
\hline \multicolumn{9}{|l|}{ Aktivitas Fisik } & \multirow{3}{*}{$\begin{array}{c}0,490 \\
(0,043-5,582)\end{array}$} \\
\hline Rendah & & 1 & 2,0 & 2 & 4,0 & 3 & 3.0 & 1,000 & \\
\hline Cukup & & 49 & 98,0 & 48 & 96,0 & 97 & 97,0 & & \\
\hline
\end{tabular}

Berdasarkan tabel 4.4 dapat diperoleh informasi bahwa dari 50 kasus, sejumlah 35 orang $(70,0 \%)$ mempunyai IMT > $25 \mathrm{~kg} / \mathrm{m}^{2}$ (obesitas), dan 15 orang $(30,0 \%)$ mempunyai IMT $<25 \mathrm{~kg} / \mathrm{m}^{2}$ (tidak obesitas). Sementara itu, dari 50 kontrol, sejumlah 17 orang $(34,0 \%)$ obesitas, dan 33 orang $(66,0 \%)$ tidak obesitas. Hasil análisis uji chi square menunjukkan bahwa nilai $p$ value $=0,001$. Hal ini menunjukan bahwa obesitas memiliki hubungan yang signifikan dengan kejadian diabetes melitus tipe II. Perhitungan risk estímate diperoleh nilai odds ratio $(\mathrm{OR}=4,529$ 231) $(95 \%$ CI 1,952-10,508), sehingga dapat disimpulkan bahwa responden yang obesitas memiliki risiko 4,529 kali untuk menderita diabetes melitus tipe II apabila dibandingkan dengan responden yang tidak obesitas.

\section{PEMBAHASAN}

Indeks massa tubuh (IMT) yang berisiko mengalami peningkatan kadar gula darah pada
Berdasarkan tabel 4.5 dapat diperoleh informasi bahwa dari 50 kasus, sejumlah 1 orang (2,0\%) memiliki aktivitas fisik rendah, dan sejumlah 49 orang $(98,0 \%)$ memiliki aktivitas fisik cukup. Sementara itu, dari 50 kontrol, sejumlah 3 orang $(3,0 \%)$ memiliki aktivitas fisik rendah, dan 48 orang $(96,0 \%)$ memiliki aktivitas fisik cukup. Hasil análisis uji chi square menunjukkan bahwa nilai $p$ value $=1,000$. Hal ini menunjukan bahwa aktivita fisik tidak ada hubungan yang signifikan dengan kejadian diabetes melitus tipe II. Perhitungan risk estímate diperoleh nilai odds ratio 0,490 (OR < 1) dapat disimpulkan bahwa aktivitas fisik merupakan faktor protektif (melindungi) atau dapat mengurangi risiko terhadap kejadian diabetes melitus tipe.

penderita DM tipe II adalah obesitas $\left(\geq 25 \mathrm{~kg} / \mathrm{m}^{2}\right.$ ). Obesitas merupakan kondisi kelebihan berat badan yang merupakan hasil dari ketidak 
seimbangan antara jumlah energi yang masuk dan energi yang keluar melalui aktivitas fisik (Soegih, 2009).

Hal ini sesuai dengan teori Suyono (2011), bahwa faktor risiko dari DM tipe II adalah faktor kegemukan/obesitas yang meliputi perubahan gaya hidup dari tradisional ke gaya hidup barat, makan berlebih, dan hidup santai (kurang gerak).

Berdasarkan hasil analisis data, hubungan obesitas dengan DM tipe II didapatkan 52 $(52,0 \%)$ yang obesitas dengan diabetes mellitus sedangkan yang tidak obesitas 48 (48,0\%). Hasil analisis dengan uji chi square menggunakan metode case control, mendapatkan hasil analisis bivariat bahwa obesitas memiliki hubungan yang signifikan dengan kejadian diabetes melitus tipe II didapatkan nilai $\mathrm{p}$ value $=0,001$ dan diperoleh OR 4,529 (95\% CI 1,952-10,508) dengan kesimpulan seseorang yang obesitas berisiko 4,529 kali dari yang tidak obesitas.

Penelitian ini sejalan dengan hasil penelitian Trisnawati (2012) yang dilakukan kandou Manado (Indonesia) mengemukakan bahwa ada hubungan signifikan antara IMT $\left(\geq 25 \mathrm{~kg} / \mathrm{m}^{2}\right)$ dengan kejadian DM tipe II dan pada kelompok kasus memiliki OR (Odds Ratio) 7,14 kali lebih besar dibandingkan dengan kelompok IMT normal. Penelitian Oba, dkk (2013) yang dilakukan di Jepang menemukan hubungan yang positif antara IMT dengan glycemic indeks dan risiko diabetes. Selain itu, penelitian Ko, dkk dan Jo, dkk (2014) yang dilakukan di Korea, menyatakan bahwa ada hubungan yang bermakna antara IMT dengan DM.

Penelitian tersebut bertentangan dengan penelitian Marieska (2014) yang dilakukan di RSUD DR. Sam Ratulangi Tondano, menyatakan tidak ada hubungan signifikan antara IMT dengan kejadian DM. Perbedaan hasil ini dapat terjadi karena adanya faktor lain yang terjadi pada saat melakukan penelitian untuk mengukur IMT penderita DM tipe 2. Penelitian tersebut sejalan dengan penelitian Puji Rahayu, dkk (2011) yang menyatakan tidak ada hubungan signifikan antara obesitas dengan kejadian DM p value $=0,185$, hal ini disebabkan banyaknya responden yang diteliti memiliki IMT $\left(<25 \mathrm{~kg} / \mathrm{m}^{2}\right)$.

Berdasarkan hasil penelitian tersebut, peneliti menyimpulkan salah satu faktor yang berkaitan erat dengan obesitas yang dapat menyebabkan responden penderita diabetes melitus tipe II di Puskesmas Olak Kemang Kota Jambi yaitu usia. Faktor usia yang berhubungan antara obesitas dengan kejadian diabetes melitus tipe II dapat di liat dari distribusi frekuensi usia diatas $\geq 45$ tahun pada kelompok kasus dan kontrol sebanyak $72 \quad(72,0 \%)$ lebih tinggi dibandingkan usia $<45$ tahun sebanyak 28 $(28,0 \%)$. Hal ini sejalan dengan penelitian yang dilakukan John S. Kekenusa, Budi T. Ratag, Gloria Wuwungan (2013) terdapat hubungan antara umur dengan DM tipe II. Orang yang berumur $\geq 45$ tahun 8 kali lebih berisiko menderita DM tipe 2 dibandingkan dengan orang yang berumur $<45$ tahun.

Faktor pendidikan yang berhubungan antara obesitas dengan kejadian DM tipe II, dikarenakan tingkat pendidikan yang rendah dan di dukung dengan distribusi frekuensi untuk kelompok kasus dan kontrol yang lebih besar pada responden yang tingkat pendidikan rendah sebanyak 93 (93,0\%). Menjelaskan bahwa hal ini lebih cenderung memiliki tingkat pengetahuan yang rendah sehingga tidak menyadari ketika mereka sakit, sehingga mempengaruhi pola konsumsi makanan yang tidak terkendali yang 
akan mengakibatkan terjadinya obesitas yang mempengaruhi penyakit DM tipe II. Menurut penelitian Dyah Surya Kusumawati (2016) bahwa ada hubungan yang bermakna antara tingkat pendidikan dengan kejadian diabetes melitus tipe II pada usia produktif $\mathrm{p}$ value = 0,011 . Tingkat pendidikan merupakan faktor resiko yag berhubungan dengan diabetes meltus tipe II di RSUD dr Soeroto Kab. Ngawi.

Berdasarkan penelitian yang dilakukan dengan menggunakan rancangan case control dengan menggunakan uji chi square, hasil yang di dapatkan adalah tidak terdapat hungungan signifikan antara aktivitas fisik dengan kejadian DM tipe II nilai $\mathrm{p}$ value $=1,000$. Hal ini menunjukan bahwa aktivita fisik tidak ada hubungan yang signifikan dengan kejadian DM tipe II dan diperoleh nilai odds ratio 0,490 dapat disimpulkan bahwa kelompok kasus tidak memiliki risiko dikarenakan $(\mathrm{OR}<1)$ karena responden pada kelompok kasus kebanyakan memiliki aktivitas fisik cukup.

Penelitian ini sejalan dengan penelitian yang dilakukan oleh Poluakan (2014), menyatakan $\mathrm{p}$ value $=0,501$ yang berarti tidak ada hubungan signifikan antara aktivitas fisik dengan kejadian DM. Hal ini juga sesuai dengan penelitian yang dilakukan sebelumnya di Rumah Sakit Umum Bunda Margonda Depok oleh Nuraini (2016), berdasarkan hasil uji statistik didapatkan nilai $\mathrm{p}$ value $=0,634$ hal ini dinyatakan bahwaa tidak ada hubungan signifikan antara aktivitas fisik dengan kejadian DM tipe II. Temuan yang sama juga dilakukan oleh Munawir (2014) di RSUD Karel sadsuitubun Langgur Maluku Tenggara, berdasarkan hasil uji statistik yang di dapatkan, tidak ada hubungan signifikan antara aktivitas fisik dengan kejadian DM tipe II dengan nilai $\mathrm{p}$ value $=0,369$. Penelitian Nurul, (2014) pada pegawai Universitas Gadjah Mada, yang melakukan medical check up di GMC Health Center Yogyakarta menyatakan hasil uji statistik didapat nilai $\mathrm{p}$-value pada variabel aktivitas fisik p value 0,634 , sehingga dapat dinyatakan bahwa tidak ada hubungan signifikan antara aktivitas fisik dengan kejadian DM tipe II.

Hal ini juga sejalan dengan penelitian yang dilakukan Regita Gebrila Rondonuwu, Sefti Rompas, Yolanda Bataha (2016) terdapat hubungan antara perilaku olahraga dengan kadar gula darah penderita diabetes mellitus.

Penelitian tersebut bertentangan dengan penelitian Trisnawati (2012) yang menyatakan bahwa ada hubungan signifikan antara aktivitas fisik dengan kejadian DM tipe II. Hal ini menyatakan bahwa memiliki nilai $\mathrm{p}$ value 0,038 - Penelitian Wasdansari (2013) juga mengungkapkan bahwa ada hubungan yang signifikan antara aktivitas fisik dengan kejadian DM tipe II. Hal ini dilakukaan dengan uji bivariat dengan nilai $\mathrm{p}$ value 0,03 dan $\mathrm{OR}=3,217$ menunjukan bahwa seseorang yang terartur melakukan olahraga dapat menurunkan risiko DM sebesar 3,217 kali dibandingkan yang tidak teratur melakukan olahraga.

Hal ini sejalan pada teori Ilyas (2009), menyatakan pada DM tipe II aktivitas fisik memiliki peran utama dalam mengatur kadar gula darah. Pada saat melakukan aktivitas fisik (berolahraga) restensi insulin berkurang, sebaliknya sensitifitas insulin meningkat, hal ini dapat menyebabkan kebutuhan insulin meningkat pada DM tipe II akan berkurang. Sensitifitas insulin meningkat dikarenakan pada saat melakukan aktivitas fisik (berolahraga) terjadinya peningkatan aliran darah. Hal ini sejala dengan penelitian yang dilakukan A Andi 
Kurniawan, dan Y Nining Sri Wuryaningsih (2016) bahwa olahraga akan memperbaiki sensitivitas insulin, meningkatkan uptake glukosa, dan memperbaiki kontrol gula darah. Olahraga yang sifatnya aerobic akan menurunkan kadar $\mathrm{HbA1C}$ dan meningkatkan sensitivitas insulin.

Menurut asumsi peneliti hasil penelitian yang berbeda dengan teori yang dikemukakan, mungkin dikarenakan responden kelompok kasus melakukan aktivitas fisik dalam batas normal (cukup) sebanyak 97 (97,0\%) tanpa melakukan aktivitas fisik tidak normal (rendah) sebanyak $3(3,0 \%)$ seperti yang disebutkan dalam beberapa teori dan penelitian sebelumnya sehingga responden tidak mengalami kejadian DM yang diakibatkan faktor risiko aktivitas fisik.

Peneliti juga menyimpulkan salah satu faktor yang berkaitan erat dengan METmenit/mingu responden dalam melakukan aktivitas fisik di Wilayah Kerja Puskesmas Olak Kemang Kota Jambi, yaitu responden pada kelompok kasus dan kontrol memiliki pekerjaan ibu rumah tangga sebanyak 59 (59,0\%) yang melakukan pekerjaan rumah setiap hari selama seminggu, dimana mereka melakukan aktivitas fisik cukup yang dihitung menggunakan METmenit/minggu. Aktivitas fisik merupakan kegiatan menggerekan tubuh yang dilakukan terus menerus dalam satu waktu tertentu yang diperoleh perhitungan MET-menit/minggu. Aktivitas fisik yang berisiko mempengaruhi peningkatan kadar gula darah adalah aktivitas fisik rendah dengan nilai MET-menit/minggu (WHO,2007). Menurut penelitian yang dilakukan oleh Trivena Merlin Palimbunga, Budi T. Ratag, Wulan. P. J. Kaunang (2016) Terdapat hubungan signifikan antara pekerjaan dengan kejadian DM tipe II dengan $(\mathrm{OR}=2,72)$ ( $\mathrm{p}$ value $=0,015)$.

\section{Kesimpulan}

1. Karakteristik responden pada penderita DM tipe II diwilayah kerja Puskesmas Olak Kemang Kota Jambi berdasarkan jenis kelamin yaitu pada kelompok perempuan sebanyak 70,0\% dibandingkan kelompok laki-laki 30,0\%, usia yaitu pada kelompok usia $\geq 45$ tahun sebanyak 92,0\% dibandingkan kelompok $<45$ tahun $8 \%$, pendidikan adalah kelompok pendidikan rendah sebanyak 94,0\% dibandingkan kelompok pendidikan tinggi $6,0 \%$, pekerjaan adalah pada kelompok pekerjaan ibu rumah tangga (IRT) sebanyak 58,0\% dan terkecil untuk kelompok pekerjaan adalah pensiunan sebanyak 2,0\%.

2. Hasil uji chi square bahwa ada hubungan yang signifikan antara obesitas dengan kejadian diabetes melitus tipe II dengan $\mathrm{p}$ value $=0,001$ dan memiliki OR (4,529) (95\% CI 1,952-10,508) yaitu responden yang obesitas memiliki risiko 4,529 kali untuk menderita diabetes melitus tipe II dibandingkan dengan responden yang tidak obesitas.

3. Hasil uji chi square bahwa tidak ada hubungan yang signifikan antara aktivitas fisik dengan kejadian diabetes melitus tipe II dengan $\mathrm{p}$ value $=1,000$ dan memiliki OR (0,490) ( CI 95\% : 0,043-5,582) bahwa aktivitas fisik merupakan faktor protektif (melindungi) atau dapat mengurangi risiko terhadap kejadian diabetes melitus tipe II.

\section{Saran}

1. Petugas kesehatan melakukan promosi kesehatan dengan upaya edukasi kepada masyarakat tentang pengendalian daan pencegahan penyakit DM tipe II kegiatan ini dapat melibatkan ibu kader prolanis di wilayah 
kerja Puskesmas Olak Kemang ataupun dalam kegiatan yang di selenggarakan oleh masyarakat seperti acara pengajian atau arisan guna peningkatan hidup sehat.

2. Petugas kesehatan harus lebih sering memotivasi semua masyarakat dan mengadakan skrining (pengecekan) di pos prolanis dan posbindu secara rutin dalam satu minggu untuk memeriksakan kadar gula darah, agar masyarakat dapat dimonitoring kadar gula darah dalam tubuh sehingga dapat mencegah terjadinya peningkatan kadar gula darah.

3. Petugas kesehatan mengaktifkan kunjungan ke rumah (Home Visit) kepada masyarakat yang mengalami penyakit DM untuk melakukan pengawasan dengan mengukur tinggi badan dan berat badan masyarakat yang mengalami IMT berlebih, agar tidak mengalami obesitas yang akan mengakibatkan penyakit komplikasi lainnya.

4. Mengoptimalkan program pengendalian penyakit DM dengan melakukan peningkatkan promosi kesehatan khususnya tentang Perilaku Hidup Bersih dan Sehat (PHBS) yang difokuskan pada Gerakan Masyarakat Hidup Sehat (GERMAS) minimal implementasi melalui; melakukan aktivitas fisik 30 menit per hari, deteksi dini penyakit tidak menular, makan buah dan sayur, dan memeriksa kesehatan secara rutin. 
Daftar Pustaka

Bustan Najib M. 2015. Epidemiologi Penyakit Tidak Menular. Edisi ke-2. Jakarta : PT. Rineka Cipta Dinas Kesehatan Kota Jambi. 2016 Data Penuyakit Diabetes Melitus di wilayah Puskesmas Kota Jambi Tahun 2016. Jambi : Dinas Kesehatan Kota

Ilyas, E.I. 2009. Olahraga bagi Diabetes .Jakarta:FKUI

Joen, dkk. 2014. Current Status of Glycemic Control of Patients with Diabetes in Korea: The Fifth Korea National Health and Nutrition Examination Survey. Diabetes \& Metabolisme Journal. Volume 38,No.2.

Kementerian Kesehatan Republik Indonesia. 2014. Petunjuk Pengukuran Risiko Diabetes Melitus. Jakarta : Direktorat P2PL

Ko, dkk. 2014. Hypertension in Patients with Diabetes than General Population: The Fifth Korea National Health and Nutrition Examination Survey in 2011. Diabetes Metabolism Journal. Volume 38, No.1.

Kurniadi Helmanu, Nurrahmani Ulfa. 2015. Stop Gejala PenyakitDiabetes Hipertensi Kolesterol Jnatung Koroner. Yogyakarta : PT. Istana Media Kurnia Andi A, Wuryaningsih Sti Nining Y, dan Indonesia Sport Medicine Center . 2016.
Rekomendasi Latihan Fisik Untuk Diabetes Melitus Tipe 2. Kusumawati Surya Dyah. 2016. Diabetes Melitus (Tipe 2) Pada Usia Produktif Dan FaktorFaktor Resiko Yang Mempengaruhinya (Studi Kasus Di Rsud Dr. Soeroto Kabupaten Ngawi).

Marieska Y,dkk. 2014. Hubungan antara IMT dan Riwayat Keluarga denga Kejadian Diabetes Melitus di RSUD Dr. Sam Ratulangi Tondando.

Maulana Mirza. 2008. Mengenal Diabetes Melitus Panduan Praktis Menangani Penyakit Kencing Manis. Jogjakarta

Murti, B. 2016. Prinsip dan Metode Riset Epidmiologi. Yuma Pustaka

Munawir. 2014. Hubungan Pola Makan dan Aktivitas Fisik dengan kejadian Daibetes Melitus tipe 2 di RSUD Karel Sadsuitubun Langgur Maluku Tenggara. Maluku Tenggara.

Nurul C. 2014. Hubungan Aktivitas Fisik dan Suku dengan Kejadian Diabetes Melitus Pada Pegawai Universitas Gadjah Mada. Yogyakarta.

Oba S, dkk. 2013.Detary glycemic index, glycemic load and incidence of type 2 diabetes in Japanese men and women: the Japan public health centerbased prospective study. Nutrition Journal.Volume 12,No.1 
Palimbungan Merlin Trivena, Ratag T. Budi, dan Kaunang P.J Wulan. 2017. Faktor-Faktor Yang Berhubungan Dengan Kejadian Diabetes Melitus Tipe 2 Di Rsu Gmim Pancaran Kasih Manado. Manado.

Poluakan Feibi Fega, dkk. 2016. Hubungan antara Aktivitas Fisik dan Riwayat Keluarga dengan Kejadian Diabetes Melitus Pada Pengunjung di Puskemas Ranotana Weru Kota Menado. Manado.

Rondonuwu Gebrila Regita, Rompas Sefti, dan Bataha Yolanda. 2016. Hubungan Antara Perilaku Olahraga Dengan Kadar Gula Darah Penderita Diabetes Mellitus Di Wilayah Kerja Puskesmas Wolaang Kecamatan Langowan Timur. Volume 4 Nomor 1.

Soegih Rachamad, Wiramihardja K Kunkun. 2009 Obesitas Permasalahan dan Terapi Praktis. Jakarta : CV. Sagung Seto
Suyono, S. 2009 Patofisiologi Diabetes Melitus dalam buku Penatalaksanaan Diabetes melitus Terpadu sebagai Panduan Pelaksanaan Diabetes Melitus bagi dokter maupun edukator diabetes. Jakarta: Fakultas Kedokteran Indonesia . Trinawati, SK dan Setyorogo. 2012 Faktor Resiko Kejadian Diabetes Melitus Tipe II Di Puskesmas Kecamatan Cengkareng Jakarta Barat Tahun 2012. (diakses 06/10/2017) : (5) (1).

Wandansari Kunthi. 2013. Hubungan Pola Makan Dan Aktivitas Fisik Dengan

Kejadian Diabetes Mellitus Tipe 2 Di Rsud Dr. Moewardi Surakarta. Surakarta.

World Health Organization (WHO). 2017. Diabetes melitus 2017 juni ( online ). Diakses 02/10/2017 Diunduh dari URL: http:// who .int 